\title{
Detection and phenotypic characterization of methicillin-resistant Staphylococcus aureus from clinical and community samples in Abakaliki, Ebonyi State, Nigeria
}

\author{
Ariom $\mathrm{TO}^{1}$, Iroha $\mathrm{IR}^{1}$, Moses $\mathrm{IB}^{1}$, Iroha $\mathrm{CS}^{2}$, Ude $\mathrm{UI}^{1}, \mathrm{Kalu}_{\mathrm{AC}}^{3}$
}

1. Department of Applied Microbiology, Ebonyi State University, Faculty of Sciences, Ebonyi State University, Abakaliki.

2. Department of Pharmacy, Federal Teaching Hospital,Abakaliki.

3. Department of Microbiology, Gregory University, Uturu, Abia State, Nigeria.

\begin{abstract}
Objective: The objective of this study was to isolate and phenotypically characterize methicillin-resistant Staphylococcus aureus (MRSA)from clinical and community samples in Abakaliki, Nigeria.

Methods: A total of 709 clinical (303) and community samples (406) samples were obtained for this study. MRSA isolates were detected using Kirby-Bauer disc diffusion method with the inclusion of $1 \mu \mathrm{g}$ oxacillin and cefoxitin antibiotic disc. The isolates were screened for the $\beta$-lactamase production using nitrocefin sticks.

Results: A total of 44 MRSA isolates were obtained from the samples with prevalence frequency of $22.6 \%$ and $20.8 \%$ from clinical and community samples respectively. The clinical isolates were completely resistant $(100 \%)$ to ceftazidime, tetracycline and penicillin. Gentamicin and ciprofloxacin were the most effective antibiotics against the clinical and community isolates respectively with a susceptibility frequency of $63.2 \%$ and $80 \%$. Exactly $38.1 \%$ and $24.2 \%$ of the clinical and community $S$. aureus isolates were positive for beta-lactamase production respectively. The HA-MRSA and CA-MRSA isolates had MARI values within the range of 0.3 to 1.0 .

Conclusion: This present findings of multi-drug resistance MRSA is very worrisome as it further highlights the pressing need to keep a strict watch on MRSA emerging from this study area.

Keywords: MRSA, beta-lactamase, antibiotics, multidrug resistance, clinical samples, community samples.

DOI: https://dx.doi.org/10.4314/ahs.v19i2.26

Cite as: Ariom TO, Iroha IR, Moses IB, Iroba CS, Ude UI, Kalu AC. Detection and phenotypic characterization of methicillin-resistant staphylococcus aureus from clinical and community samples in Abakaliki, Ebonyi State, Nigeria. Afri Health Sci.2019;19(2): 2026-2035. bttps:/ / dx.doi.org/ 10.4314/abs.v19i2.26
\end{abstract}

\section{Introduction}

Globally, antibiotic resistance has become a growing concern in the public health sector. This is because resistance often results in treatment failure, which can have serious consequences especially in critically ill patients ${ }^{1}$. Resistant bacteria may spread and create broader infection control problems, both within healthcare institutions and in the community. Multiple antibiotic resistant Staphylococcus

\section{Corresponding author:}

Moses Ikechukwu Benjamin,

Department of Applied Microbiology,

Faculty of Science,

Ebonyi State University,

P.M.B. 053, Abakaliki, Ebonyi State,

Nigeria

Tel: +2348134136233

Email: ben_iyke70@yahoo.com aureus are major threats to patients care, owing to their stubborn intransigence to chemotherapy and disinfection $^{2}$. Prolonged therapy with methicillin may lead to the development of low-level resistance that compromise therapy, but may not be detected by routine susceptibility testing methods used in hospital laboratories ${ }^{3}$. S. aureus has been implicated in a wide range of infections ranging from acute to chronic infections such as boils, bacteriuria, osteomyelitis, pneumonia, endocarditis, meningitis, septicaemia and arthritis. This organism is a leading cause of human bacterial infection worldwide and is endemic in hospitals and communities ${ }^{4}$. The bacterium is frequently found on the skin and anterior nares of healthy individuals. However, it predominates in surgical wound infections with prevalence ranging from $4.6 \%$ to $54.4 \% 0^{5}$. Most Staphylococcal infections are associated with serious community-acquired and nosocomial diseases which arise often in individuals with predisposing risk factors such as haemodialysis or surgery. It causes superficial,
African

Health Sciences

(C) 2019 Ariom et al. Licensee African Health Sciences. This is an Open Access article distributed under the terms of the Creative commons Attribution License (https://creativecommons.org/licenses/BY/4.0), which permits unrestricted use, distribution, and reproduction in any medium, provided the original work is properly cited. 
deep-skin, soft tissue infections, endocarditis and bacteremia with metastatic abscess formation and a variety of toxin-mediated diseases including gastroenteritis, staphylococcal scalded skin syndrome, toxic shock syndrome, meningitis, septicaemia and arthritis ${ }^{6}$. The emergence of antimicrobial resistance makes the effective management and treatment of infections caused by methicillin-resistant Staphylococcus aureus difficult. This study, is therefore, designed to evaluate the prevalence of methicillin-resistant Staphylococcus aureus in Abakaliki, Ebonyi State.

\section{Materials and methods Sample collection}

A total of seven hundred and nine samples were collected for this study. Three hundred and three were clinical samples [wound, pus, urine, high vaginal swab (HVS) (41), ear swab, sputum and semen of patients visiting Federal Teaching Hospital Abakaliki (FETHA I and II) and Mile Four General Hospital, Abakaliki while 406 [(nasal and ear swabs] were community samples. Wound, pus, HVS and ear swab samples were collected using sterile swab sticks while urine, semen and sputum samples were collected using sterile specimen bottles. In the same way, the four hundred and six (406) community samples (nasal and ear swabs) were collected from apparently healthy tutors (121), artisans (62), secondary school students of Abakaliki high school (153) and petty traders from Kpirikpiri Market (70). The Hospital patients' group encompasses individuals who are at greater risk of becoming infected by this opportunistic pathogen. These individuals are generally older, have chronic underlying illnesses, and require more frequent interactions with healthcare facilities; all of which predispose them to more serious infections. The Community group includes individuals who, in general, are otherwise healthy. They are usually not predisposed by age or underlying illness to these infections, but predisposed by specific activities and community interactions that place them at an increased risk for infection contraction. The collected samples were immediately transported to the Department of Applied Microbiology Laboratory unit of Ebonyi State University, Abakaliki for bacteriological analysis.

\section{Culturing, isolation, characterization and identifica- tion of the isolates}

The clinical and community samples were aseptically inoculated on Mannitol Salt broth (Oxoid, UK) and in- cubated at $37^{\circ} \mathrm{C}$ for 48 hours. A loopful of the inoculated mannitol salt broth was later streaked on mannitol salt agar (MSA, Oxoid, UK) and incubated at $37^{\circ} \mathrm{C}$ for 24 hours. The plates were observed for creamy golden colonies typical of S.aureus. Purified colonies were later cultured on sheep blood agar. Colonies displaying beta-haemolysis on sheep blood agar were presumptively identified as $S$. aureus. These suspected $S$. aureus isolates were further characterized using conventional/standard microbiology techniques such as colony morphology, Gram-staining, catalase test, motility test and other biochemical tests which include oxidase test, indole test, H2S production test, Voges-Proskauer test, methyl red test, sugar fermentation test, coagulase test and Staphylococcus lactase agglutination assay as described $\mathrm{by}^{7,8,9}$.

\section{Antibiotic susceptibility test}

The susceptibility patterns of isolated $S$. aureus isolates were determined by the Kirby and Bauer disc diffusion method as recommended by CLSI ${ }^{10}$. Each of the isolate wasstandardized to $0.5 \mathrm{McF}$ arland equivalent and aseptically inoculated on prepared Muller-Hinton agar (Oxoid, UK) plates using sterile swab stick. The inoculated plates were allowed to stand for 10-15 min. Antibiotic impregnated discs namely penicillin $\mathrm{G}(10 \mu \mathrm{g})$, tetracycline $(30$ $\mu \mathrm{g})$, gentamicin $(30 \mu \mathrm{g})$, nitrofurantoin $(300 \mu \mathrm{g})$, erythromycin $(15 \mu \mathrm{g})$, ciprofloxacin $(5 \mu \mathrm{g})$, ceftazidime (30 $\mu \mathrm{g})$, sulphamethoxazole $(25 \mu \mathrm{g})$ and clindamycin $(2 \mu \mathrm{g})$ (Oxoid, UK) were placed on the inoculated plates using sterile forceps. The plates were incubated at $37^{\circ} \mathrm{C}$ for $24 \mathrm{~h}$ after which the zones of inhibition around each disc were measured to the nearest $\mathrm{mm}$ with a metre rule, recorded and interpreted according to the Clinical Laboratory Standard Institute (CLSI) guidelines ${ }^{10}$.

\section{Detection of methicillin resistant Staphylococcus aureus (MRSA)}

This was done using Kirby Bauer disc diffusion method according to Clinical and Laboratory Standard Institute (CLSI) guidelines ${ }^{10}$. A Mueller-Hinton agar plate was prepared according to its manufacturer's specification. Colonies of the isolated bacteria were suspended in $5 \mathrm{ml}$ of nutrient broth. The turbidity of the broth culture was adjusted to $0.5 \mathrm{McF}$ arland standard, which approximately equals 1.5 x $108 \mathrm{CFU} / \mathrm{ml}$. Standardized inoculum was swabbed onto the prepared Mueller-Hinton agar plate. After at least 3 min, antibiotic discs impregnated with ox- 
acillin and cefoxitin were placed on Mueller-Hinton agar plate for MRSA detection. The plate was then incubated at $37^{\circ} \mathrm{C}$ for 24 hours. Inhibition zone diameter was measured to nearest millimeter and interpreted according to CLSI guidelines.

\section{Beta-Lactamase detection using Nitrocefin stick}

This was done to detect the production of beta-lactamases by the $S$. aureus isolates. Before inoculation, the nitrocefin stick was allowed to cool to room temperature. A drop of distilled water was used to moderately moisten the tip of the nitrocefin stick. After this, the colour coded end of the stick was used to touch the colony by making sure that the reagent on the brown tip of the stick was rotated to pick mass of the cells. The colour coded tip was observed after 5 minutes for pink-red colour development to show the production of beta-lactamase.

\section{Determination of multiple antibiotic resistance in- dex (MARI)}

Multiple antibiotic resistance indices (MARI) of the S. aureus isolates were calculated using the technique described by Christopher et al. ${ }^{11}$ and Subramani et al. ${ }^{12}$. This was calculated as the number of antibiotics to which the tested isolate was resistant to (a), divided by the total number of antibiotics that was tested on the isolates (b). MARI $=$ Number of antibiotics to which the tested isolate was resistant to (a) / Total number of antibiotics tested (b)

\section{Results}

Table 1: Clinical samples collected from Federal Teaching Hospital Abakaliki (FETHA I)

\begin{tabular}{|c|c|c|c|c|}
\hline $\begin{array}{l}\text { Sample } \\
\text { source }\end{array}$ & $\begin{array}{l}\text { No. } \\
\text { of samples }\end{array}$ & collected & $\begin{array}{l}\text { No. of } S \text {. aureus } \\
\text { isolated }\end{array}$ & $\begin{array}{c}\text { No. of } \\
\text { MRSA isolated }\end{array}$ \\
\hline Wound swab & 21 & & 11 & 4 \\
\hline Urine & 33 & & 6 & 1 \\
\hline High vaginal swab & 11 & & 2 & 0 \\
\hline Sputum & 7 & & 2 & 2 \\
\hline Ear swab & 17 & & 9 & 2 \\
\hline Pus & 7 & & 2 & 0 \\
\hline Semen & 21 & & 4 & 0 \\
\hline TOTAL & 117 & & $36(30.8 \%)$ & $9(25 \%)$ \\
\hline
\end{tabular}


Table 2: Clinical samples collected from Federal

Teaching Hospital Abakaliki (FETHA II)

\begin{tabular}{|c|c|c|c|}
\hline $\begin{array}{c}\text { Sample } \\
\text { source }\end{array}$ & No. of samples collected & $\begin{array}{l}\text { No. of } S \text {. aureus } \\
\text { isolated }\end{array}$ & $\begin{array}{c}\text { No. of } \\
\text { MRSA isolated }\end{array}$ \\
\hline Wound swab & 10 & 7 & 2 \\
\hline Urine & 35 & 7 & 2 \\
\hline $\begin{array}{l}\text { High vaginal } \\
\text { swab }\end{array}$ & 13 & 4 & 1 \\
\hline Sputum & 8 & 2 & 0 \\
\hline Ear swab & 10 & 5 & 1 \\
\hline Pus & 9 & 4 & 1 \\
\hline Semen & 18 & 2 & 0 \\
\hline TOTAL & 103 & $31(30.1 \%)$ & $7(22.6 \%)$ \\
\hline
\end{tabular}

Table 3: Clinical samples collected from mile four general hospital Abakaliki

\begin{tabular}{|c|c|c|c|}
\hline $\begin{array}{l}\text { Sample } \\
\text { source }\end{array}$ & No. of samples collected & $\begin{array}{l}\mathrm{N}_{0} \text { of } \mathrm{S} \text {. aurreus } \\
\text { isolated (\%) }\end{array}$ & $\begin{array}{c}\text { No. of } \\
\text { MRSA isolated }\end{array}$ \\
\hline Wound swab & 5 & 3 & 1 \\
\hline Urine & 31 & 4 & 0 \\
\hline High vaginal swab & 17 & 3 & 0 \\
\hline Sputum & 20 & 3 & 0 \\
\hline Ear swab & 10 & 4 & 2 \\
\hline Pus & 0 & 0 & 0 \\
\hline Semen & 0 & 0 & 0 \\
\hline T0TAL & 83 & $17(20.5 \%)$ & $3(17.7 \%)$ \\
\hline
\end{tabular}


Table 4: Samples collected from apparently healthy individuals in the community

\begin{tabular}{|c|c|c|c|c|c|c|}
\hline \multirow{2}{*}{ Occupatio } & \multicolumn{2}{|c|}{ Ear Swab } & \multicolumn{2}{|l|}{ Nasal Swab } & \multicolumn{2}{|l|}{ Total } \\
\hline & $\begin{array}{l}\text { No of } \\
\text { Samples }\end{array}$ & $\begin{array}{l}\text { No of Staph. } \\
\text { Isolated }\end{array}$ & $\begin{array}{l}\text { No of } \\
\text { Samples }\end{array}$ & $\begin{array}{l}\text { No of Staph. } \\
\text { Isolated }\end{array}$ & Sample & Isolate \\
\hline Tutors & 66 & 25 & 55 & 19 & 121 & 44 \\
\hline Artisans & 32 & 13 & 30 & 9 & 62 & 22 \\
\hline Students & 73 & 18 & 80 & 14 & 153 & 32 \\
\hline $\begin{array}{l}\text { Petty } \\
\text { Traders }\end{array}$ & 38 & 12 & 32 & 10 & 70 & 22 \\
\hline Total & 209 & 68 & 197 & 52 & 406 & $120(29.6 \%)$ \\
\hline
\end{tabular}


Table 5: Prevalence of MRSA in Hospital and community isolates

\begin{tabular}{llllll}
\hline & \multicolumn{5}{c}{ MRSA } \\
\cline { 2 - 5 } $\begin{array}{l}\text { Sample } \\
\text { source }\end{array}$ & $\begin{array}{l}\text { No. of } \\
\text { isolate } \\
\text { tested }\end{array}$ & FETHA I & FETHA II & Mile Four & No. positive \\
\hline Hospital & $84(27.7 \%)$ & $9(47.4 \%)$ & $7(36.8 \%)$ & $3(15.8 \%)$ & $\mathbf{1 9 ( 2 2 . 6 \% )}$ \\
\hline \multirow{2}{*}{ Community } & $\begin{array}{l}\text { 120(29.6 } \\
\text { \%) }\end{array}$ & & & $\mathbf{2 5}(\mathbf{2 0 . 8} \mathbf{\%})$ \\
\hline
\end{tabular}

Table 6: Occupational distribution of population with community acquired methicillin resistant staphylococcus aureus (CA-MRSA)

\begin{tabular}{|c|c|c|c|c|c|c|c|}
\hline \multirow[t]{3}{*}{ Occupation } & \multirow{3}{*}{ Swab } & \multirow{2}{*}{\multicolumn{2}{|c|}{ ar }} & \multirow{2}{*}{\multicolumn{2}{|c|}{$\begin{array}{l}\text { Nasal } \\
\text { Swab }\end{array}$}} & \multirow[t]{2}{*}{ Total } & \multirow[t]{3}{*}{ Total } \\
\hline & & & & & & & \\
\hline & & M & F & M & F & $\mathbf{M} \mathbf{F}$ & \\
\hline Tutor & 2 & 4 & 2 & 3 & 4 & 7 & $\overline{11}$ \\
\hline Artisan & 3 & 1 & 1 & 2 & 4 & 3 & 7 \\
\hline Petty Trader & 1 & 2 & 0 & 0 & 1 & 2 & 3 \\
\hline Student & 0 & 2 & 1 & 1 & 1 & 3 & 4 \\
\hline \multirow[t]{2}{*}{ TOTAL } & & 5 & 9 & 4 & 6 & 1015 & 25 \\
\hline & & & 15 & 10 & & & \\
\hline
\end{tabular}

Key: $M=$ Male $F=$ Female

Table 7: Beta-lactamase detection in Hospital and community isolates

\begin{tabular}{lccc}
\hline Source & $\begin{array}{l}\text { No of isolates } \\
\text { tested }\end{array}$ & Beta-lactamase positive & $\begin{array}{l}\text { Beta-lactamase } \\
\text { negative }\end{array}$ \\
\hline Hospital & 84 & 32 & 52 \\
Community & 120 & 29 & 91 \\
\hline Total & $\mathbf{2 0 4}$ & $\mathbf{6 1}$ & $\mathbf{1 4 3}$ \\
\hline
\end{tabular}




\section{Discussion}

Staphylococcus aureus has long been recognized as the cause of a variety of infectious diseases ranging from mild conditions like soft tissue infections, to severe life threatening debilitation such as endocarditis ${ }^{13}$. Infections caused by methicillin-resistant $S$. aureus (MRSA) represent a growing public health problem and a challenge for health care institutions ${ }^{14}$. Regardless of serious efforts employed to control antibiotic resistant bacteria by aggressive infectioncontrol methods, antibiotic resistant Staphylococci, especially MRSA, has become the most frequent cause of hospital and community acquired infections worldwide $^{15,16}$.

In this study, $36(30.8 \%)$ S. aureus isolates were obtained from the 117 clinical samples collected from FETHA I. Nine $(25 \%)$ out of these isolates were identified as MRSA (Table 1). In FETHA II, 31 (30.1\%) S. aureus isolates were obtained from the 103 clinical samples collected from patients. Seven $(22.6 \%)$ of these isolates were identified as MRSA (Table 2). In Mile Four Hospital, 17 $(20.5 \%) S$. aureus isolates were obtained from 83 clinial samples. Three $(17.7 \%)$ of the isolates were identified as MRSA (Table 3). One hundred and twenty (29.6\%) $S$. aureus isolates were obtained from the 496 community samples (nasal and ear swabs) collected from tutors, artisans, students and petty traders (Table 4). This study is in agreement with the research conducted in Osogbo, South-western Nigeria by Olowe et al. ${ }^{17}$ who reported the isolation of $42.9 \% \mathrm{~S}$. aureus from Staphylococci isolates in Osogbo, South-western Nigeria. Nineteen (22.6\%) isolates were confirmed to be MRSA out of the $84 \mathrm{~S}$. aureus isolated from the clinical samples (wound, pus, urine, HVS, ear swab, sputum and semen) (Table 5). Similarly, $25(20.8 \%)$ community-associated methicillin resistant S. aureus (CA-MRSA) were detected from the 120 Staphylococcus aureus isolates obtained from the community samples of nasal and ear swabs (Table 5). The distribution of MRSA isolated from the three major hospitals in Abakaliki showed that the highest prevalence frequency of MRSA was found in FETHA I [9 (47.4\%)].

This was closely followed by FETHA II [(7 (36.8 \%)] and Mile Four General Hospital [(3 (15.8\%)] being the least (Table 5). The highest number of MRSA was isolated from wound samples (7); followed by ear swabs (5), urine (3) and sputum (2). HVS and pus recorded the least number of MRSA as they each had one isolate. There was no MRSA isolate from semen samples (Tables 1, 2 and 3). This is similar tothe report by Olowe et al. ${ }^{17}$ who reported that wound samples had the highest prevalence of MRSA. Many researchers have reported an increase in the incidence of MRSA most of which originated from wounds ${ }^{18}$. CA-MRSA was most predominant among tutors (11). The overcrowded nature of tutors' staff rooms and irrational use of antibiotics might possibly be the reason for the high prevalence of MRSA among them. This is because overcrowded living places have been seen as one of the risk factors for CA-MRSA ${ }^{19}$. The least number of CA-MRSA was observed among petty traders (Table 6). CA-MRSA isolates were more prevalent in ear swabs than in nasal swabs (Table 6). This result is in concord with the work of Falagas et al. in South Africa ${ }^{20}$. They reported MRSA prevalence of $23 \%$. The same researchers later reported a slightly higher prevalence frequency of $24 \%$ and $20 \%$ for HA-MRSA and CA-MRSA respectively in another research they conducted in the same area some years later. Similar observation was also made by Borg et al. who recorded MRSA prevalence rate of 18 $\%$ in a research they conducted in 4 hospitals in Tuni$\mathrm{sia}^{21}$. The present research recorded lower prevalence rate when compared with the result of Olowe et al. ${ }^{17}$ who recorded a higher MRSA prevalence frequency of $47.7 \%$. Another study conducted in South-western Nigeria is also in agreement with the report of this present study. The research reported a HA-MRSA prevalence rate of 20.23 $\%$ where 70 out of $346 \mathrm{~S}$. aureus isolates were methicillin resistant22. The CA-MRSA prevalence rate of $20.8 \%$ reported in this work is similar to that reported in another research conducted by Lucianne et al. ${ }^{23}$ who reported a CA-MRSA prevalence of $27.8 \%$.

The MRSA isolates (HA-MRSA) obtained from the clinical samples in the hospitals were multidrug resistant as they were resistant to at least two classes of antibiotics (Figure 1). All the HA-MRSA isolates were completely resistant $(100 \%)$ to ceftazidime, tetracycline and penicillin. This was closely followed by ciprofloxacin (94.7\%), nitrofurantoin $(89.5 \%)$, clindamycin $(89.5 \%)$ and erythromycin $(78.9 \%)$. The most effective antibiotic against the HA-MRSA isolates was gentamicin as $63.2 \%$ of the isolates were susceptible to this antibiotic (Figure 1). This is in agreement with the work of Ibrahim et al. ${ }^{24}$ where antibiotic susceptibility results of $S$. aureus showed absolute 
resistance $(100 \%)$ against ampicillin, and high resistance against cefotaxime $(81 \%)$, while resistance frequencies to ceftriaxone, erythromycin, ciprofloxacin, trimethoprim, gentamicin, levofloxacin and clindamycin were $59 \%, 59$ $\%, 41 \%, 41 \%, 35 \%, 23 \%$ and $18 \%$, respectively. The susceptibility frequency of MRSA isolates to gentamicin in this study is similar to the findings of Tiwari et al. ${ }^{25}$ who reported a high susceptibility frequency of MRSA isolates to gentamicin. The CA-MRSA isolates were also multidrug resistant. All the HA-MRSA isolates were completely resistant $(100 \%)$ to ceftazidime, sulphamethoxazole and penicillin. This was closely followed by gentamicin $(80 \%)$, nitrofurantoin $(80 \%)$, clindamycin $(80$ $\%)$ nd tetracycline $(60 \%)$. Interestingly, ciprofloxacin, and erythromycin were the most effective antibiotics against the CA-MRSA in contrast to the HA-MRSA in which gentamicin was the most effective antibiotic (Figure 2). These resistances might result from inappropriate prescriptions due to lack of standard treatment guidelines ${ }^{26}$. In developing countries, an estimated $50 \%$ of those who need antimicrobials do not have access to them due to cost. Sometimes, these drugs are not taken by patients as prescribed and some people indulge in self-medication ${ }^{27}$. Relentless exposure of bacterial strains to a large number of $\beta$-lactams has induced active and continuous production and mutation of $\beta$-lactamases in these bacteria, thus expanding their activity even against the newly developed $\beta$-lactam antibiotics. Thirty-two (32) MRSA (or HA-MRSA) isolates out of the 84 clinical samples of $S$. aureus isolates were positive for beta-lactamase production while 29 CA-MRSA isolates were positive for beta-lactamase production (Table 7). This is in agreement with the findings of Terry et al. ${ }^{28}$ in South-East Nigeria who reported that $124(64 \%)$ of their $S$. aureus isolates were able to produce $\beta$-lactamase enzyme by changing colour from yellow to red on the addition of nitrocefin solution. Production of $\beta$-lactamase in $S$. aureusis reported to have been consistently high in Nigeria ${ }^{29}$. They reported that $70-80 \%$ of $S$. aureus isolates produced $\beta$-lactamase. Other researchers reported such high $\beta$-lactamase prevalence ${ }^{30,31}$. The spread of $\beta$-lactamase genes had been enhanced by their integration within mobile genetic elements such as plasmids and transposons which facilitate the rapid transfer of genetic materials between microbes ${ }^{32}$. Multidrug resistant bacteria have created therapeutic problems especially to healthcare providers and, its consistent emergence will only cause hazard to the public health ${ }^{33}$. The HA-MR-
SA isolates had MARI values within the range of 0.7 to 1.0. These high MARI values depict the high resistances of these isolates to antibiotics (Table 8). The MARI values for the CA-MRSA ranged from 0.3 to 0.7 . These values are also high but lower than the MARI values for HA-MRSA which exhibited higher antibiotic resistance potential (Table 9).

Our study is in agreement with the report of Subramani and Vignesh ${ }^{34}$ who revealed that all the $S$. aureus isolates in their study had very high MARI values of above 0.2. This indicates that the bacterial isolates may have been exposed to several antibiotics and the selective pressure of the antibiotics used in the management of bacterial infections could be the main reason for resistance apart from the bacteria acquiring the resistance gene through mutation or interspecies gene transmission ${ }^{35}$.

\section{Conclusion}

This study shows that misuse of antibiotics could possibly lead to a change in microbial resistance characteristics, causing treatment failure and increase in the cost of infection control. This report further reveals that MRSA isolates are present in some major hospitals in Abakaliki and within the community in Abakaliki, Ebonyi State, Nigeria. Gentamicin, ciprofloxacin and erythromycin are still effective against MRSA infections. Obviously, if the infections caused by MRSA are not controlled, it will spread to larger population of people in the community thereby causing a very serious public health problem especially among the immunocompromised. Therefore, there is urgent need to keep a strict watch on MRSA emerging from this research study area.

\section{Conflict of interest statement}

The authors declare that there are no conflicts of interest

\section{References}

1. Fred, C. Mechanism of Antimicrobial Resistance in Bacteria. The American Journal of Medicine. (2006) 119 (6A): 55-510.

2. Slade D, Lindner A. B., Paul G., Radman M. Recombination and replication in DNA repair of heavily irradiated Deinococcus radiodurans. Cell. (2009) 136: 1044-1055.

3. Tenover, F. C., Weigel, L. M., Appelbaum, P. C. Vancomycin Resistant Staphylococcus aureus Isolation from a $\mathrm{Pa}-$ tient in Rennsylvania. Journal of Antimicrobial Agents Chemotherapy. (2004) 48: 275-280. 
4. Chambers, H.F and Deleo, F.R. Waves of Resistant Staphylococcus aureus in the Antibiotics Era. Journal Review Microbiology. (2009) 7: 629-641.

5. Rallapalli S., Verghese S., Verma R. S. Validation of multiplex PCR strategy for simultaneous detection and identification of methicillin resistant Staphylococcus aureus. Indian J Medical Microbiol. (2008) 26(4): 361-364.

6. Amghalia, E., Nagi, A AL-Haj., Mariana, Shamsudin, N., Son Radu., RozitaRosli, Neela V. and Raha A. Rahim, A. Multiplex PCR Assay for Detection of Clinically Relevant Antibiotic Resistance Genes in Staphylococcus aureus Isolated from Malaysian Hospitals. Research Journal of Biological Sciences. (2009) 4 (4): 444-448.

7. Bannerman T. L. Staphylococcus, Micrococcus, and other catalase positive cocci that grow aerobically. In: Murray PR, Baron EJ, Jorgensen JH, Pfaller MA, Yolken RH, ed. Manual of clinical microbiology. ASM Press: Washington DC. (2003) 8: 384-404.

8. Cheesbrough, M. District Laboratory Practice in Tropical Countries, Part Two, 2ndEdition. Cambridge University Press, UK (2004) 134-180.

9. Chandrashekhar, G. U and Basappa, B. K. Phenotypic Characterization and Risk Factors of Nosocomial Staphylococcus aureus from Health Care Centers. Advances in Microbiology. (2012) 2: 122-128.

10. Clinical and Laboratory Standard Institute. Performance Standard for Antimicrobial Susceptibility Testing, $17^{\text {th }}$ Information Supplement (M100-517). Wayne, Pa: Clinical and Laboratory Standard Institute. (2009).

11. Christopher A. F., Hora S., and Ali Z. Investigation of plasmid profile antibiotic susceptibility pattern multiple antibiotic resistance index calculation of Escherichia coli isolates obtained from different human clinical specimens at tertiary care hospital in Bareilly-India. ATMPH (2013) 6:285-289.

12. Subramani P, Shanmugam N, Sivaraman U, Kumar S, Selvaraj S. Antibiotic resistance pattern of biofilm-forming uropathogens isolated from catheterised patients in Pondicherry, India. Australas Med J. (2012) 5(7):344-348. 13. Morellion P., Que Y. A., Glauser M. P. Staphylococcus aureus (including Staphylococcal toxic shock). In: Mandell G. L., Bennett J. E., Dolin R. eds. Principles and Practices of Infectious Diseases. 6th ed. Philadelphia, PA: Elsevier Inc. (2005) 2321-50.

14. Lepelletier D, Perron S, Bizouarn P, Caillon J, Drugeon H, Michaud J. L, Duveau D. Surgical-site infection after cardiac surgery: Incidence, microbiology, and risk factors. Infect Control Hosp Epidemiol. (2005) 26:466-72. 15. Anupurba S, Sen M. R., Nath G., Sharma B. M., Gulati A. K., Mohapatra T. M. Prevalence of methicillin resistant Staphylococcus aureus in a Tertiary care Referral Hospital in Eastern Uttar Pradesh. Indian J Med Microbiol., (2003) 21: 49-51.

16. Taiwo, S.S., Bamidele, M., Omonigbehin, E.A., Akinsunde, K.A., Smith, S.I., Onile, B.A. and Ilowe, A. O. Molecular epidemiology of methicillin resistance $S$. aureus in Ilorin, Nigeria. West Afri.J. Med. (2005) 24 (2): 100 - 6. 17. Olowe, O. A., Eniola, K. I. T., Olowe, R. A., \& Olayemi, A. B. Antimicrobial Susceptibility and Beta-lactamase detection of MRSA in Osogbo, SW Nigeria. Nature and Science. (2007) 5(3): 44-48.

18. Vidhani, S., Mehndiratta, P. L and Mathur, M. D. Study of methicillin resistant Staphylococcus aureus (MRSA) isolates from high risk patients. Indian J. Med. Microbiol. (2001) 9 (2): 13-16.

19. Scerri J, Monecke S, Borg M. A. Prevalence and characteristics of community carriage of methicillin-resistant Staphylococcus aureus in Malta. J Epidemiol Glob Health. (2013) 3:165-173.

20. Falagas ME, Karageorgopoulos DE, Leptidis J, Korbila IP. MRSA in Africa: Filling the Global Map of Antimicrobial Resistance. PLoS One. (2013) 8(7): e68024.

21. Borg MA, De Kraker M, Scicluna E. Prevalence of methicillin resistant Staphylococcus aureus (MRSA) in invasive isolates from southern and eastern Mediterranean countries. Journal of Antimicrobial Chemotherapy. (2007) 60: 1310-1315.

22. Ghebremedhin, B., Olugbosi, M.O., Raji, A.M., Layer, F., Bakare, R.A., Konig, B., Konig, W. Emergence of a Community-Associated Methicillin-Resistant Staphylococcus aureus with Unique Resistance Profile in Southwest of Nigeria. Journal of Clinical Microbiology. (2009) 47: 29752980.

23. Lucianne dos S, Cibeli V, Gabriela F, Luciana KO, Adalberto VG. Antimicrobial susceptibility of strains Staphylococcus aureus and Staphylococcus coagulase-negative isolated from cows'milk with mastitis in the West of Paraná, Brazil. Enciclopédia Biosfera. (2013) 9(17): 213-223.

24. Ibrahim M. E., Magzoub M. A., Bilal N. E., Hamid M. E. Distribution of Class I integrons and their effect on the prevalence of multi-drug resistant Escherichia coliclinical isolates from Sudan. Saudi Med J. (2013) 34:240-247.

25. Tiwari H. K., Sen M. R. Emergence of vancomycin 
resistant Staphylococcus aureus (VRSA) from a tertiary care hospital from northern part of India. BMC Infectious Disease. (2006) 6: 156-161.

26. World Health Organisation (WHO). Antimicrobial resistance; 2015. Avaliable at http://www.who.int/mediacentre/factsheets/fs194/en/.

27. World Health Organization. Critically Important Antimicrobials for Human Medicine [2nd Revision]; 2009. Available at: http://www.who.int/foodsafety/foodbornedisease/CIA2ndrev 2009.pdf.

28. Terry-Alli O.A., Ogbolu D.O., Akorede E., Onemu O.M., and Okanlawon B.M. Distribution of mecA gene amongst Staphylococcus aureus isolates from south western Nigeria. African Journal of Biomedical Research. (2011) 14:9-16.

29. Torimiro, N., Moshood, A. A and Eyiolawi, S.A. Analysis of Beta-lactamase Production and Antibiotics Resistance in Staphylococcus aureus Strains. Journal of Infectious Diseases and Immunity. (2013) 5(3) 24-28.

30. Kesah C. N., Ogunsola F. T., Neemogha M. T., Odungbemi T. O. An in-vitro Study of Methicillin and Other Antimicrobial Agent against Staphylococcus aureus, 1994 -1996, Nig Qt.J. Hosp Med. (1997) 7(3): 286-88.
31. Akindele, A.A., Adewuyi, I.K., Adefioye, O.A., Adedokun, S.A., Olaolu, A.O. Antibiogram and Beta-lactamase of Staphylococcus aureus isolates from different human Clinical Specimens in a Tertiary Health Institution in Ile-Ife, Nigeria. Am Eurasian Journal of Science Res. (2010) 5(4):230-233.

32. Wilke, M.S., Lovering, A. L., Strynadka, C.J.N. $\beta$-lactam Antibiotic Resistance: A Current Structural perspective. Curr. Microbiol. (2005) 8: 525-533.

33. Amalia, A.R., Ramzi, O.S.B. and Son, R. Antibiotic resistance evolution of Methicillin Resistant Staphylococcus aureus (MRSA) and colloidal silver as the nano-weapon. International Food Research Journal. (2016) 23(3): 12481254.

34. Subramani S. and Vignesh. MAR Index Study and MDR Character Analysis of a few Golden Staph Isolates. Asian Journal of Pharmacy and Life Science(2012) 2(2): 151 154.

35. Poonia, S., Singh, T.S. and Tsering, D.C. Antibiotic susceptibility profile of bacteria isolated from natural sources of water from rural areas of East Sikkim. Indian Journal of Community Medicine. Official Publication of Indian Association of Preventive and Social Medicine. (2014) 39(3): 156-160. 